\title{
On Farm Partial Budget Analysis of Hot Pepper (Capsicum annuum L.) Cultivars for Dry Pod to the Application of Blended Fertilizer and Urea Rates in Raya Azebo District, Northern Ethiopia
}

\author{
Wakuma Biratu ${ }^{1}$ Derbew Belew ${ }^{2}$ Edossa Ettissa ${ }^{3}$ \\ 1.Ethiopian Institute of Agricultural Research, Mehoni Agricultural Research Center \\ 2.Jimma University College of Agriculture and Veterinary Medicine \\ 3.Ethiopian Institute of Agricultural Research, Melkassa Agricultural Research Center
}

\begin{abstract}
The experiment was conducted to draw information on the economic feasibility of the application of blended fertilizer and urea rates on hot pepper cultivars (Melka Awaze and Melka Shote) under Raya Azebo Agroecological Condition. The experiment consisted of two hot pepper cultivars (Melka Shote and Melka Awaze) and five NPSZn + urea rates and one without fertilizer as a control. The trial was conducted to determine the most profitable rate/s of NPSZn + urea on selected two hot pepper cultivars. Two factor experiment $\left(2^{*} 6\right)$ was arranged in RCBD with three replications. For the achievement of this objective, marketable red dry pod yield data was collected and analyzed using SAS version 9.3. The highest marketable $\left(2.29 \mathrm{t} \mathrm{ha}^{-1}\right)$ yield was recorded when Melka Shote cultivar was combined with $84.5 \mathrm{NPSZn}+136.5$ urea $\mathrm{kg} \mathrm{ha}^{-1}$. In terms of economic feasibility, application of fertilizer at the rate of 84.5 NPSZn +136.5 urea kg ha $^{-1}$ to Melka Shote cultivar was found to be the most profitable, which gave net benefit of $132037 \mathrm{ETB} \mathrm{ha}^{-1}$ and marginal rate of return above the acceptable minimum rate of return $(51.63 \%$.). Thus, at Mehoni agricultural research site and for the surrounding farmers in Raya Azebo and other areas which have similar agro-ecological conditions, application of $84.5 \mathrm{NPSZn}+136.5$ urea $\mathrm{kg} \mathrm{ha}^{-1}$ to Melka Shote cultivar is recommended to obtain maximum economic return. However, to give sound recommendation it is important to repeat the experiment at this location in different season.
\end{abstract}

Keywords: Cultivars; Net benefit;Melka Awaze; Melka Shote

DOI: $10.7176 / \mathrm{DCS} / 11-4-02$

Publication date: April $30^{\text {th }} 2021$

\section{Introduction}

Agronomic trials address a significant problem for an identifiable group of farmers with similar conditions, and test solutions that are potentially feasible for farmers to adopt (Boughton et al., 1990). To determine the feasibility of a particular technology, partial budget analysis is commonly used for different agronomic trials. According to CIMMYT (1988), partial budget analysis is a simple but effective technique for distinguishing the profitability of new technology for an existing enterprise. It also provides the foundation for comparing the relative profitability of alternative treatments, evaluating their riskiness, and testing how robust profits are in the event of changing product or input prices.

Partial budgets analysis involves, eliminating dominated treatments (those incurring higher costs but no additional net benefit), determining the marginal rate of return between remaining treatments of incremental cost, and comparing these MRRs to the acceptable minimum rate of return. The treatment with the highest net benefit together with an acceptable MRR becomes the tentative recommendation, subject to sensitivity and risk analysis

All these terms: partial budget, marginal analysis and minimum rate of return together provide the information necessary to arrive at a tentative or candidate recommendation. This is the treatment with the highest net benefit per hectare and a marginal rate of return greater than the minimum acceptable rate of return (CIMMYT, 1988). The level of net benefit which is the difference between the value of the additional output and/or resources saved and the value (opportunity cost) of additional resources is an important criterion for farmers when they evaluate alternative technologies. Minimum returns analysis seeks to incorporate farmers' concerns about risk into the evaluation. Whereas marginal analysis is based on average yields across all sites, minimum returns analysis examines the variation in returns from individual sites (CIMMYT, 1988; Boughton et al., 1990).

Hot pepper is amongst the vegetable crops widely grown at Raya Valley and used as vegetable, spice, medicine and ornamental. However, the production, productivity and the net profit that farmers were getting from hot pepper is low particularly at Raya Valley. As indicated by MoARD (2009), actual dry pod yield of different hot pepper cultivars ranged from $1.5 \mathrm{t} \mathrm{ha}^{-1}$ to $3.0 \mathrm{t} \mathrm{ha}^{-1}$. From this, Melka Shote cultivar had the highest yield ranging from 2.5 to $3.0 \mathrm{t} \mathrm{ha}^{-1}$ as compared to the other cultivars. While, Melka Awaze cultivar ranged from $2.5-2.8 \mathrm{t} \mathrm{ha}^{-1}$. In Ethiopia, green and red pepper covers an area of 190,533.74 hectare which shares about $79.5 \%$ of the total area occupied by vegetable crops $(239,609.76$ hectares $)$ at the national level. In terms of production, 
green and red peppers share $48.2 \%$ of vegetable production whereby 391,598.6 tonnes of both peppers produced at the national level with yield per hectare of 1.83 and $6.3 \mathrm{t} \mathrm{ha}^{-1}$ for red and green peppers respectively (CSA, 2017).

The average output ha ${ }^{-1}$ for green and red dry pod is low as compared to that of world average production and the actual yield of pepper cultivars which in turn lowers the profit from the farm. This could be due to different profitability and productivity limiting factors including shortages of improved cultivars, inadequate seed production and promotion, poor extension works, susceptibility of released cultivars to diseases, poor agronomic practices (plant population, irrigation amount and frequencies, fertilizer type and level) across location, seasons with corresponding cultivars and market instability (Fekadu and Dandena, 2006; Shumeta, 2012; Getahun and Habtie, 2017). To solve these problems, only some research activities like adaptation trial on hot pepper (Gebremeskel et al., 2015), DAP and urea rates (Teka, personal communication, 2017) have been undertaken.

However, no researches have been done in determining the profitability of the treatments particularly while applying fertilizer. Currently, blended fertilizer is replacing the blanket recommendation DAP and urea so determining the rate/s at which growers capable to obtain the highest profit which helps them to achieve sustainable production and improve their livelihood.

Thus, this work is initiated with the objective:

$\checkmark$ To asses economic profitability of NPSZn + urea rate on selected hot pepper cultivars

$\checkmark$ To identify the most economically feasible rate/s of NPSZn + urea for selected hot pepper cultivars

\section{MATERIALS AND METHODS}

\subsection{Description of the Study Area}

The field experiment was carried out at MhARC, under irrigation condition. The center is situated at about 678 $\mathrm{km}$ to the north of the capital, Addis Ababa, in Raya Azebo southern Tigray zone. As metrological class of the center indicated, geographically the area is located at $12^{\circ} 41^{\prime} 50^{\prime \prime}$ North latitude and $39^{\circ} 42^{\prime} 08^{\prime \prime}$ East longitude with an altitude of $1578 \mathrm{~m}$.a.s.l. The site receives mean annual rainfall of $750 \mathrm{~mm}$. The average minimum and maximum temperature of the site is 18 and $25^{\circ} \mathrm{C}$, respectively. The soil textural class of the experimental area is clay loam with $\mathrm{pH}$ of 7.9 .

\subsection{Treatment and experimental ddesign}

The experiment consisted of five blended $\left(\mathrm{N}_{-} \mathrm{P}_{2} \mathrm{O}_{5}-\mathrm{S}-\mathrm{Zn}\right)+$ urea fertilizer rates, one without fertilizer as control and two selected hot pepper cultivars (Table 1). For a reference of $\mathrm{N}_{-} \mathrm{P}_{2} \mathrm{O}_{5}-\mathrm{S}-\mathrm{Zn}$ which have percentage composition of $17.7 \mathrm{~N}-35.3 \mathrm{P}_{2} \mathrm{O}_{5}+6.5 \mathrm{~S}+2.5 \mathrm{Zn}$, the blanket recommendation of Urea and DAP for hot pepper production at Raya Azebo was used. The blanket recommendation of $\mathrm{N}$ and $\mathrm{P}$ at Raya Azebo was $60 \mathrm{~kg}^{-1}$ (130.4 $\mathrm{kg} \mathrm{Urea} \mathrm{ha}^{-1}$ ) and $10 \mathrm{~kg} \mathrm{ha}^{-1}\left(22.9 \mathrm{~kg} \mathrm{P}_{2} \mathrm{O}_{5}\right)$ respectively (Teka, personal communication, 2017). So, apply $22.9 \mathrm{~kg} \mathrm{ha}^{-1}$ of $\mathrm{P}_{2} \mathrm{O}_{5}$ in the form of NPSZn, $65 \mathrm{NPSZn} \mathrm{kg} \mathrm{ha}^{-1}$ is required. When $65 \mathrm{NPSZn} \mathrm{kg} \mathrm{ha}^{-1}$ applied, 11.5 $\mathrm{kg} \mathrm{ha}^{-1}$ of $\mathrm{N}$ was applied concurrently; thus, to apply the recommended $\mathrm{N}\left(60 \mathrm{~kg} \mathrm{ha}^{-1}\right)$ in parallel with NPSZn, $48.5 \mathrm{~N}$ is left. So, the remaining $\mathrm{N}$ was applied in the form of urea which is $105 \mathrm{~kg} \mathrm{ha}^{-1}$. Accordingly, $65 \mathrm{~kg}$ of NPSZn and $105 \mathrm{~kg}$ of Urea ha ${ }^{-1}$ were used as the reference. The rest levels of NPSZn + urea was arranged by adding and subtracting $30 \%$ and $60 \%$ of the rate used as a reference (Table 2). Of the total $\mathrm{N}$ intended to be applied in the form of urea, 30.8\% of each rate which are $(13.2,22.6,32.3,42$ and $51.7 \mathrm{~kg}$ for $42.8,73.5,105$, 136 and $168 \mathrm{~kg}$ of urea, respectively) were applied at transplanting with NPSZn and the rest was applied at 45 days from transplanting. The treatments were laid down in randomized complete block design (RCBD) with factorial arrangement $(2 * 6=12)$ with three replications.

Planting material: two commercial cultivars of hot pepper namely Melka Shote and Melka Awaze were introduced from Melkassa Agricultural Research Center (MARC). For the basis of cultivar selection, there was an adaptation trial conducted on different hot pepper cultivars (Melka Shote, Mareko Fana, Melka Zala and Melka Awaze) at Raya valley. From the result, both Melka Shote and Melka Awaze cultivar was recommended for the farmers at that location (Gebremeskel et al., 2015). 
Table 2. Description of treatment combinations of blended fertilizer with pepper cultivars

\begin{tabular}{|c|c|c|c|c|c|c|}
\hline \multirow[t]{2}{*}{ No. } & \multicolumn{2}{|r|}{ Treatments } & \multicolumn{4}{|c|}{ Nutrients concentration } \\
\hline & Cultivars & Fertilizer NPSZn Kg/ha & $\mathrm{N}$ & $\mathrm{P}_{2} \mathrm{O}_{5}$ & $\mathrm{~S}$ & $\mathrm{Zn}$ \\
\hline 1 & MA & 0 & 0 & 0 & 0 & 0 \\
\hline 2 & & 26 NPSZn +42.8 Urea & 24 & 9 & 1.7 & 0.65 \\
\hline 3 & & 45.5 NPSZn +73.5 Urea & 42 & 16 & 3 & 1.13 \\
\hline 4 & & 65 NPSZn + 105 Urea & 60 & 23 & 4.2 & 1.63 \\
\hline 5 & & 84.5 NPSZn +136.5 Urea & 78 & 30 & 5.3 & 2.11 \\
\hline 6 & & 104 NPSZn + 168 Urea & 96 & 37 & 6.7 & 2.6 \\
\hline 7 & MS & 0 & 0 & 0 & 0 & 0 \\
\hline 8 & & 26 NPSZn +42.8 Urea & 24 & 9 & 1.7 & 0.65 \\
\hline 9 & & 45.5 NPSZn +73.5 Urea & 42 & 16 & 3 & 1.13 \\
\hline 10 & & 65 NPSZn +105 Urea & 60 & 23 & 4.2 & 1.63 \\
\hline 11 & & 84.5 NPSZn +136.5 Urea & 78 & 30 & 5.3 & 2.11 \\
\hline 12 & & 104 NPSZn + 168 Urea & 96 & 37 & 6.7 & 2.6 \\
\hline
\end{tabular}

$\mathrm{MA}=$ Melka Awaze cultivar, MS = Melka Shote cultivar

\subsection{Data Collected}

The highest gross average dry pod yield $\left(\mathrm{t} \mathrm{ha}^{-1}\right)$ (GADPY) may not mean the highest net benefit or the maximum return that farmers are interested to obtain. In order to come up with the conclusive recommendation of the treatment/s which is/are economically feasible, it is important to look for partial budget analysis which helps to estimate the total costs that vary and the net benefits for each treatment of an experiment (CIMMYT, 1988). To undertake this, average yields hectare ${ }^{-1}$ for each treatment, the adjusted yields, the gross field benefit and the total costs were collected as follows.

Gross average dry pod yield (t ha $\mathbf{~ h}^{-1}$ ) (GADPY): Is average yield of each treatment hectare ${ }^{-1}$

Adjusted yield (AY): Is the marketable yield adjusted downward by a 10\% to reflect the difference between yield obtained under the management of researchers and yield of farmers (CIMMYT, 1988).

AY $\left(\mathrm{t} \mathrm{ha}^{-1}\right)=$ GADPY $-($ GADPY $* 0.1)$

Gross field benefit (GFB) (ETB ha-1): It was obtained by multiplying price from the farm that farmers get when they sale the adjusted yield. The average price of dried hot pepper pods meanwhile the season the experiment conducted was $100 \mathrm{ETB} / \mathrm{kg}^{-1}$

$\mathrm{GFB}=\mathrm{AY}^{*}$ farm gate price for the crop

Total variable cost: It is the cost of fertilizers (NPSZn + urea), labour costs for weeding/hoeing and seed costs. Net benefit (NB) (ETB/ha): Was the difference between gross field benefit and total cost for each treatment. $\mathrm{NB}=\mathrm{GFB}-$ total cost

Marginal rate of return (MRR \%): was the ratio of change in net benefit to change in cost and expressed in percentage. The maximum net benefit alone is not reliable to recommend for the producer. In most of cases, farmers or producer prefer the highest profit (low cost high income). For this reason, it is necessary to find MRR by identifying and omitting the dominated treatment. The indispensability of dominance analysis was to simplify subsequent calculations by ignoring dominant treatments (any treatment with net benefits less than or equal to those of a treatment with lower cost) (Boughton et al., 1990; CIMMYT, 1988).

$\mathrm{MRR}=\Delta \mathrm{NB} / \Delta \mathrm{TVC}$ Or MRR $(\%)=$ Marginal benefit $/$ Marginal Cost $\times 100$

\section{RESULTS AND DISCUSION}

\subsection{Partial Budget Analysis}

3.1.1. Net Benefit Analysis

The net benefit was estimated for 12 treatments as illustrated in (Table 2). Net benefit was increased linearly up to a certain level in both cultivars although the total costs that vary were increased as long as the rate of the NPSZn + urea increases. Accordingly, the application of 84.5 NPSZn +136.5 urea kg ha ${ }^{-1}$ on Melka Shote cultivar had gave the highest net benefit which is 132037 ETB followed by the application of 65 NPSZn +105 urea $\mathrm{kg} \mathrm{ha}^{-1}$ on Melka Awaze cultivar which gave net benefit of 108404 ETB. While the lowest net benefit (44027.1 ETB) was obtained when Melka Awaze cultivar kept unfertilized, followed by unfertilized Melka Shote (48527.1 ETB) cultivar.

Application 84.5 NPSZn +136.5 urea kg ha-1 on Melka Shote cultivar which gave net benefit of 132037 ETB was the most profitable treatment and the peak fertilizers rate to apply to this cultivar. While, the second most profitable is the application of $65 \mathrm{NPSZn}+105$ urea kg ha-1 on Melkaawaze cultivar which gave net benefit of 108404 ETB and the peak NPSZn + urea rate to apply. As the total costs that vary increased over the optimum level, the net benefit achieved above this level is not enough to compensate the cost beyond the cost of optimum rates of NPSZn + urea fertilizers (reduced net benefit or high cost of production and low net benefit). 
Table 3. Net benefit return analysis for the application blended fertilizers rates (NPSZn) and urea on hot pepper cultivars.

\begin{tabular}{|c|c|c|c|c|c|}
\hline Treatment & $\begin{array}{l}\text { GADPY } \\
\left(\mathrm{t} \mathrm{ha}^{-1}\right)\end{array}$ & $\begin{array}{l}\text { AY } \\
\left(\mathrm{t} \mathrm{ha}^{-1}\right)\end{array}$ & $\begin{array}{l}\text { TC } \\
\left(\mathrm{ETB} \mathrm{ha}^{-1}\right)\end{array}$ & $\begin{array}{l}\text { GFB } \\
\left(\text { ETB ha-1) }^{-1}\right.\end{array}$ & $\begin{array}{l}\text { NB } \\
\left(\text { ETB ha-1) }^{-1}\right)\end{array}$ \\
\hline MA (0 NPSZn + urea kg ha-1) & 1.28 & 1.15 & 71172.93 & 115200 & 44027.10 \\
\hline MA (26 NPSZn +42.8 urea kg ha-1) & 1.50 & 1.35 & 72072.53 & 135000 & 62927.50 \\
\hline MA (45.5 NPSZn +73.5 urea kg ha-1) & 1.85 & 1.67 & 72729.03 & 166500 & 93771.00 \\
\hline MA (65 NPSZn +105 urea kg ha-1) & 2.02 & 1.82 & 73395.93 & 181800 & 108404.00 \\
\hline MA (84.5 NPSZn +136.5 urea kg ha-1) & 1.93 & 1.74 & 74062.83 & 173700 & $99637.2 \mathrm{D}$ \\
\hline MA (104 NPSZn + 168 urea kg ha $\left.{ }^{-1}\right)$ & 1.65 & 1.49 & 74729.73 & 148500 & 73770.3D \\
\hline MS (0 NPSZn + urea kg ha-1) & 1.33 & 1.20 & 71172.93 & 119700 & 48527.10 \\
\hline MS (26 NPSZn +42.8 urea kg ha-1) & 1.73 & 1.56 & 72072.53 & 155700 & 83627.50 \\
\hline MS (45.5 NPSZn +73.5 urea kg ha') & 1.89 & 1.70 & 72729.03 & 170100 & 97371.00 \\
\hline MS (65 NPSZn + 105 urea kg ha' $)$ & 1.90 & 1.71 & 73395.93 & 171000 & 97604.10 \\
\hline MS (84.5 NPSZn + 136.5 urea kg ha-1) & 2.29 & 2.06 & 74062.83 & 206100 & 132037.0 \\
\hline MS (104 NPSZn + 168 urea kg ha-1) & 1.85 & 1.67 & 74729.73 & 166500 & 91770.3D \\
\hline
\end{tabular}

$\mathrm{D}=$ Dominant treatment, MA $=$ Melka Awaze, $\mathrm{MS}=$ Melka Shote, GADPY $=$ Gross average dry pod yield $\left(\mathrm{t}\right.$ ha ${ }^{-}$ $\left.{ }^{1}\right), \mathrm{AY}=$ Adjusted yield, $\mathrm{TC}=$ Total cost, $\mathrm{GB}=$ Gross benefit, NB = Net benefit

Price of inputs: Hot pepper seed/Kg $=300$-birr, Urea $=13$ birr kg-1, NPSZn $=13.2$ birr kg $\mathrm{kg}^{-1}$, Price of dry pod = 100 birr kg ${ }^{-1}$, Labor cost $=50$ birr for one person day $^{-1}$.

3.1.2. Dominance analysis and marginal rate of return

The result from dominant analysis showed that the net benefit of treatment five (application of 84.5 NPSZn + 136.5 urea kg ha ${ }^{-1}$ on Melka Awaze cultivar) and the application of $104 \mathrm{NPSZn}+168$ urea kg ha-1 to both cultivars (Melka Awaze and Melka Shote) were dominated and left to consider for further analysis (Table 3). The net benefit of these treatments was decreased as the total cost increased above undominated treatments; thus, it may not be accepted by the growers.

Relaying on the maximum net benefit by omitting the dominant treatments alone is not enough to recommend the most profitable treatment (technologies) to the farmers rather estimating the marginal rate of return. Marginal rate of return (MRR) is the ratio of marginal net benefit to marginal variable costs expressed in percentage (Boughton et al., 1990; CIMMYT, 1988). However, recommending treatment/s based on marginal rate of return alone is not reliable rather than based on the minimum acceptable rate of return. Then treatments having minimum rate of return above or equal to $50 \%$ is acceptable in most cases of fertilizer level trial (CIMMYT, 1988)

The most profitable treatment is application of $84.5 \mathrm{NPSZn}+136.5$ urea kg ha-1 to Melka Shote cultivar gave net benefit of (132037 $\mathrm{ETB} \mathrm{ha}^{-1}$ ) and marginal rate of return above minimum acceptable rate of return which is $51.63 \%$. The second is application of $45.5 \mathrm{NPSZn}+73.5$ urea $\mathrm{kg} \mathrm{ha}^{-1}$ to Melka Awaze which gave marginal rate of return below the minimum acceptable rate of return. Thus, to obtain optimum economic return from the production of hot pepper at study area, it is recommended to apply 84.5 NPSZn $+136.5 \mathrm{urea} \mathrm{kg} \mathrm{ha}^{-1}$ to Melka Shote cultivar. In the case when this cultivar is not available it is advisable to use Melka Awaze cultivar in combination with blended fertilizer and urea at the rate of 45.5 NPSZn +73.5 urea kg ha-1.

Table 4. Dominance analysis and marginal rate of return for the application blended fertilizers rates (NPSZn) and urea on hot pepper cultivars.

\begin{tabular}{|c|c|c|c|c|c|}
\hline Treatment & $\begin{array}{l}\text { TC } \\
\left(\text { ETB ha-1) }^{-1}\right)\end{array}$ & $\begin{array}{l}\text { NB } \\
\left(\mathrm{ETB} \mathrm{ha}^{-1}\right)\end{array}$ & $\mathrm{B}: \mathrm{C}$ ratio & $\mathrm{MRR} \%$ & Rank \\
\hline MA (0 NPSZn + urea kg ha-1) & 71172.93 & 44072.10 & 0.62 & & \\
\hline MA (26 NPSZn +42.8 urea $\left.\mathrm{kg} \mathrm{ha}^{-1}\right)$ & 72072.53 & 62927.50 & 0.87 & 21.01 & \\
\hline MA (45.5 NPSZn +73.5 urea kg ha-1) & 72729.03 & 93771.00 & 1.29 & 46.98 & 2 \\
\hline MA (65 NPSZn +105 urea kg ha-1) & 73395.93 & 108404.00 & 1.48 & 21.94 & \\
\hline MA (84.5 NPSZn + 136.5 urea kg ha $\left.{ }^{-1}\right)$ & 74062.83 & 99637.20D & 1.35 & & \\
\hline MA (104 NPSZn + 168 urea kg ha-1) & 74729.73 & 73770.30D & 0.99 & & \\
\hline MS (0 NPSZn + urea kg ha-1) & 71172.93 & 48527.10 & 0.68 & & \\
\hline MS (26 NPSZn +42.8 urea kg ha-1) & 72072.53 & 83627.50 & 1.16 & 10.96 & \\
\hline MS (45.5 NPSZn + 73.5 urea kg ha-1) & 72729.03 & 97371.00 & 1.34 & 20.95 & \\
\hline MS (65 NPSZn + 105 urea kg ha' $)$ & 73395.93 & 97604.10 & 1.33 & 0.35 & \\
\hline MS (84.5 NPSZn +136.5 urea kg ha-1) & 74062.83 & 132037.00 & 1.78 & 51.60 & 1 \\
\hline MS (104 NPSZn + 168 urea kg ha-1) & 74729.73 & 91770.30D & 1.23 & & \\
\hline
\end{tabular}

MA = Melka Awaze, MS= Melka Shote, $\mathrm{D}=$ dominated treatments; TVC=Total variable cost; NB=Net benefit; $\mathrm{B}: \mathrm{C}$ ratio=Benefit cost ratio; $\mathrm{MRR} \%=$ marginal rate of return, $\mathrm{MRR}=$ change in net income $/$ change in cost $\mathrm{x}$ 100 


\section{Summary and Conclusions}

Hot pepper (Capsicum annuum L.) is the most widely cultivated and economically important crop. Shortage of information on agronomic practices particularly the right fertilizer rate with respective of cultivar across location and season are among the production, productivities and profitability limiting issue. Thus, the study was initiated to determine economically the most profitable rate of NPSZn on selected two hot pepper cultivars in Raya Azebo district at Mehoni Agricultural Research study site. Generally, the experiment consisted of two cultivars and five different level of NPSZn + urea and one without fertilizer application (control) and arranged in Factorial (2 X 6) combination in Randomized Complete Block Design.

The highest marketable dried pod yield (2.29 $\left.\mathrm{t} \mathrm{ha}^{-1}\right)$ was recorded when Melka Shote cultivar combined with $84.5 \mathrm{NPSZn}+136.5$ urea $\mathrm{kg} \mathrm{ha}^{-1}$. Whereas, the lowest marketable dried pod yield $\left(1.28 \mathrm{t} \mathrm{ha}^{-1}\right)$ was recorded from the interaction of Melka Awaze with control $\left(0 \mathrm{~kg} \mathrm{ha}^{-1}\right)$. Application of fertilizer at the rate of $84.5 \mathrm{NPSZn}$ +136.5 urea $\mathrm{kg} \mathrm{ha}^{-1}$ to Melka Shote cultivar was found to be the most profitable rate, which gave net benefit of $132037 \mathrm{ETB} \mathrm{ha-1}$ and marginal rate of return above the acceptable minimum rate of return (51.63\%.). Thus, at Mehoni agricultural research site and for the surrounding farmers in Raya Azebo and other areas which have similar agro-ecological conditions, application of $84.5 \mathrm{NPSZn}+136.5$ urea kg ha ${ }^{-1}$ to Melka Shote cultivar is tentatively recommended to obtain maximum economic return. However, to give sound recommendation it is important to repeat the experiment at this location in different season.

\section{Acknowledgements}

Chiefly, I thank Almighty God since He gave me the health, strength and kept me peace to undertake all my past events.

I would like to show my appreciation to Ethiopian Institute of Agricultural Research for giving me the chance to join the school of graduate studies; and in their help in budget for undertaking the activity.

Also, my gratitude for Mr. Haile Abebe (Researcher at MhARC in the Field of Horticultre), Halefom Hailu (Technical assistance in the field of Horticulture), Tewodiros Abreha (Technical assistance in the field of Horticulture) and Genet Kebede (Field assistance in the Horticulture case team) who helped me starting from nursery establishment to the end of the field experiment during, seeding, transplanting, data collection and field management.

\section{References}

ATA, 2015. Soil fertility mapping and fertilizer Recommendation in Ethiopia: Update of EthioSIS project and status of fertilizer blending Agricultural Transformation Agency. Ethiopia $108 \mathrm{p}$.

Boughton, D., Crawford, E., Krause, M. and de Frahan, B. H., 1990. Economic analysis of on-farm trials: a review of approaches and implications for research program design. Michigan State University, Michigan, pp. $1-48$

CSA (Central Statistical Authority of Ethiopia), 2017. Agricultural sample survey. Report on area and production of major crops. Volume I, Statistical bulletin 584. Addis Ababa, Ethiopia.

CSA, 2006. Agricultural Sample Survey. Report on area and productivity of crops. Statstical Bulletin, Volume I. Addis Ababa.361p.

CSA, 2012. Agricultural sample survey. Report on Crop and livestock product utilization, Volume VII.

Fekadu M. and Dandena G., 2006. Review of the status of vegetable crops production and marketing in Ethiopia. Uganda J. Agric. Sci, 12(2), pp.26-30.

Gebremeskel H., Abebe H., Biratu W., and Jaleto K., 2015. Performance evaluation of hot pepper (Capsicum annum L.) cultivars for productivity under irrigation at Raya Valley, Northern Ethiopia. Basic Res. J. Agric. Sci. Rev, 4(7), pp.211-216.

Getahun D. and Habtie B., 2017. Growth and Yielding Potential of Hot Pepper Cultivars under Rain-Fed Production at Woreta, Northwestern Ethiopia. International Journal of Research Studies in Agricultural Sciences, 3(3). pp11-18.

MoARD, 2009. Improved technologies and resource management for Ethiopian agriculture. In: Mandefro N., Anteneh G., Chimdo A. and Abebe K. (eds.), Training manual. Rural Capacity Building Project Addis Ababa, Ethiopia, pp 1 -312.

Prasd K., Saradhi P. P, Sharmila P., 1999. Concerted action of antioxidant enzymes and curtailed growth under zinc toxicity in Brassica juncea. Environmental and experimental Botany, 42: pp.1-10.

Shumeta Z., 2012. Hot pepper production and marketing in southwest Ethiopia: An alternative enterprise for small scale farmers. J. Trends Agric. Econ, 5(3), pp.83-95. 